\title{
Relationship Between Basic Laboratory Results and Fibrosis in Chronic Hepatitis B Patients
}

\section{Kronik Hepatit B Hastalarında Temel Laboratuvar Sonuçları ile Fibrozis Arasındaki Illișki}

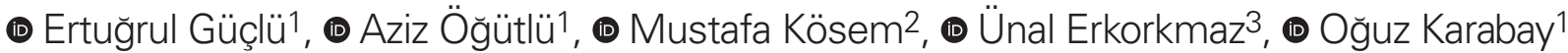

1 Sakarya University Faculty of Medicine, Department of Infectious Diseases and Clinical Microbiology, Sakarya, Turkey

2Sakarya University Faculty of Medicine, Department of Pathology, Sakarya, Turkey

${ }^{3}$ Sakarya University Faculty of Medicine, Department of Biostatistics, Sakarya, Turkey

\begin{abstract}
Objectives: Liver biopsy (LB) is an important cornerstone in decision to start treatment for chronic hepatitis B (HB). Viral load and liver function tests are performed to determine the most appropriate time. In this study, factors affecting liver fibrosis in hepatitis $\mathrm{B}$ e antigen ( $\mathrm{HBeAg}$ ) negative chronic hepatitis $\mathrm{B}$ patients were investigated.

Materials and Methods: LB and the other laboratory results such as alanine aminotransferase (ALT), aspartate aminotransferase (AST), gamma-glutamyl transpeptidase (GGT), and hepatitis B virus (HBV)DNA were collected from patient files, retrospectively. According to study protocol, necroinflammatory scores $\leq 4$ and fibrosis scores $\leq 1$ were accepted as normal liver (NL), and the high value in one of these scores was accepted as chronic hepatitis $(\mathrm{CH})$.

Results: A total of 234 patient's LBs included in the study. A total of 74 (31.6\%) patients' LB was evaluated as NL. In univariate analysis, age, gender, ALT, AST, GGT, AFP and HBV-DNA >100.000 IU/mL, and in multivariate analysis, age, AST level $>29 \mathrm{U} / \mathrm{L}$, and AFP level $>2.5 \mathrm{ng} / \mathrm{mL}$ were the independent risk factors for $\mathrm{CH}$.

Conclusion: According to our results, age, AST and AFP predict $\mathrm{CH}$. Doctors who follow up chronic hepatitis $\mathrm{B}$ patients should be carefully evaluate these parameters when giving LB decision.

Keywords: Chronic hepatitis B, Liver biopsy, Fibrosis
\end{abstract}

ÖZ

Amaç: Kronik hepatit B tedavisine başlama kararını vermede karaciğer biyopsisi önemli bir mihenk taşıdır. Uygun zamanı belirlemek için viral yük ve karaciğer fonksiyon testleri ile takip yapılmaktadır. Bu çalışmada hepatit $\mathrm{B}$ e antigen ( $\mathrm{HBeAg}$ ) negatif kronik hepatit B hastalarında karaciğer fibrozisini etkileyen faktörler araştırıldı.

Gereç ve Yöntemler: Karaciğer biyopsisi ve alanin aminotransferaz (ALT), aspartat aminotransferaz (AST), gama-glutamil transpeptidaz (GGT) ve hepatit B virüs (HBV)-DNA gibi laboratuvar testleri geriye dönük olarak hasta dosyalarından toplandı. Çalışma protokolüne göre nekroenflamatuvar skor $\leq 4$ ve fibrozis skoru $\leq 1$ tespit edilenler normal karaciğer (NK), bu skorlardan birindeki yüksek değer kronik hepatit (KH) olarak kabul edildi.

Bulgular: Çalışmaya toplam 234 hastanın karaciğer biyopsisi dahil edildi. Toplam $74(\% 31,6)$ hastanın biyopsi sonucu NK olarak kabul edildi. Tek değişkenli analizlerde yaş, cinsiyet, ALT, AST, GGT, AFP ve HBV-DNA $>100,000 \mathrm{IU} / \mathrm{mL}$ düzeyi NK ve $\mathrm{KH}$ arasında istatistiksel olarak farklıydı. Çok değişkenli analizlerde ise yaş, AST >29 U/L ve AFP $>2,5 \mathrm{ng} / \mathrm{mL}$ düzeyi $\mathrm{KH}$ için bağımsız risk faktörüydü.

Sonuç: Sonuçlarımıza göre, yaş, AST ve AFP, KH'yi öngörmektedir. Kronik hepatit B hastalarını izleyen doktorlar, karaciğer biyopsisi kararı alırken bu parametreleri dikkatli bir şekilde değerlendirmelidir. Anahtar Kelimeler: Kronik hepatit B, karaciğer Biyopsisi, Fibrozis

Güçlü E, Öğütlü A, Kösem M, Erkorkmaz Ü, Karabay O. Relationship Between Basic Laboratory Results and Fibrosis in Chronic Hepatitis B Patients. Viral Hepat J. 2019;25:45-49.

Address for Correspondence: Ertuğrul Güçlü MD, Sakarya University Faculty of Medicine, Department of Infectious Diseases and Clinical Microbiology, Sakarya, Turkey Phone: +902648884000 E-mail: ertugrulguclu@hotmail.com ORCID: orcid.org/0000-0003-2860-2831 Received: 11.02.2019 Accepted: 23.04.2019

${ }^{\circ}$ Copyright 2019 by Viral Hepatitis Society / Viral Hepatitis Journal published by Galenos Publishing House. 


\section{Introduction}

Hepatitis B virus (HBV) infect the liver and can lead to a broad spectrum of disease, ranging from an inactive carriage to cirrhosis and hepatocellular carcinoma (HCC) (1). The overall hepatitis B surface antigen (hBsAg) seropositivity in Turkey was 4\% $(2.3 \%$ in the western and $7.3 \%$ in the eastern regains (2).

Chronic hepatitis $\mathrm{B}(\mathrm{CHB})$ may present either as hepatitis $\mathrm{B}$ e antigen ( $\mathrm{HBeAg}$-positive or $\mathrm{HBeAg}$-negative. HBeAg-negative form of the disease has been increasing. In Turkey, HBeAg-negative form is the most prevalant form (90\%) (3). European Association for the Study of the Liver guidelines recommended antiviral therapy for $\mathrm{HBeAg}$-negative $\mathrm{CHB}$ patients if their liver biopsy showing at least moderate necroinflammation and/or at least moderate fibrosis when their alanine aminotransferase (ALT) level higher than the upper limit of normal (ULN) and HBV-DNA levels above $2.000 \mathrm{IU} / \mathrm{mL}$. Patients with HBV-DNA $>20.000 \mathrm{IU} / \mathrm{mL}$ and ALT >2 $x$ ULN can start treatment even without a liver biopsy (1). However, approximately one third of patients who have persistently normal ALT levels have moderate inflammation and/or advanced fibrosis, particularly patients older than 35 years old $(4,5)$. So, the sufficiency of monitoring $\mathrm{HBeAg}$-negative patients with ALT is controversial. Liver biopsy is often recommended for determining the degree of necroinflammation and fibrosis since hepatic histology can asist the decision to start treatment (6). In this study, we aimed to investigate factors that affect the degree of necroinflammation and fibrosis in liver biopsiy, in $\mathrm{HBeAg}$-negative $\mathrm{CHB}$ patients.

\section{Matherials and Methods}

This study was conducted in a tertiary care hospital. Liver biopsy results between 2009 and 2013 were collected from patient files retrospectively. Demographic characteristics and laboratory parameters which were made with in one year before liver biopsy were obtained from the patients' files, too.

\section{Inclusion criteria for patients;}

- Being HBsAg-positive for at least six months,

- Being HBeAg-negative and anti-HBe positive,

- Being older than 18 years,

- Antiviral and interferon therapy naive patients.

\section{Exclusion Criteria for Patients}

- Coinfection with hepatitis C virus, hepatitis D virus or human immunodeficiency virus,

- A co-existing disease (Wilson disease, hemochromatosis, autoimmune disease, HCC or other malignant diseases

- A history of using systemic corticosteroid, antineoplastic or immunomodulator drugs.

\section{The Biopsy Decision}

The indications for liver biopsy are based mainly on the combination of three criteria; serum HBV-DNA levels, serum ALT levels and age. ULN of ALT was accepted as $35 \mathrm{U} / \mathrm{L}$.

- Liver biopsy was performed in all patients with ALT above 2 times ULN and serum HBV-DNA above $20.000 \mathrm{IU} / \mathrm{mL}$.

- In patients who have serum HBV-DNA above $2.000 \mathrm{IU} / \mathrm{mL}$ but normal ALT levels, liver biopsy was performed when the second HBV-DNA determination was found above $2.0001 \mathrm{U} / \mathrm{mL}$ again during 3-6 months period and the patients' age was above 35 years.

Biopsy procedure: Percutaneous liver biopsy was performed with tru-cut biopsy method. Disposable 16-18 G semi-automatic tru-cut biopsy needles (Geotek Healthcare products, Turkey; Matek Medical Inc, Turkey) was used in the biopsies. Obtained specimens were sent to pathology laboratory in formalin. Grading and staging of histological activity index was scored with the modified Ishac score system (7).

Necroinflammatory scores $\leq 4$ and fibrosis scores $\leq 1$ were accepted as normal or minimally affected liver (NL) (8). The high value in one of these scores was accepted as $\mathrm{CH}$.

The study protocol was approved by the Ethics Committee of Sakarya University Faculty of Medicine (approval number: 2013/71522473.050.01.04/37). This study was carried out in accordance with the principles of the Helsinki Declaration).

\section{Statistical Analysis}

Kolmogorov-Smirnov test was used to evaluate whether the distribution of variables were normal. Therefore, two independent Sample t-test was used to compare the normal distributed continuous variables between groups. The normal distributed continuous variables were presented as the mean \pm standard deviation. Mann-Whitney $U$ test was used to compare the nonnormal distributed continuous variables between groups. The non-normal distributed continuous variables were presented as the median and interquartile range (quartile 1 to 3). Categorical variables were compared by Pearson's or Yates corrected chi-square tests. Categorical variables were presented as a count and percentage.

Receiver operating characteristic (ROC) curve analysis was performed to establish the most accurate diagnostic method (biomarker) to discriminate between $\mathrm{CH}$ and normal patients. $\mathrm{ROC}$ curves were constructed for ALT, aspartate aminotransferase (AST), gamma-glutamyl transpeptidase (GGT), and alpha-fetoprotein (AFP) to test the various biomarkers in predicting $\mathrm{CH}$ (Figure 1). The areas under the ROC curves (AUC) were calculated and the specificity, sensitivity, positive-predictive value, negative-predictive value, accuracy, for the ALT, AST, GGT and AFP of the most appropriate cut-off point were calculated for predicting $\mathrm{CH}$. A multivariate logistic regression model was implemented to determine ALT, AST, GGT and AFP and other covariates associated with $\mathrm{CH}$. A p-values $<0.05$ were considered significant. Analyses were performed using commercial software (IBM SPSS Statistics 20, SPSS inc., an IBM Co., Somers, NY; MedCalc 12.7, MedCalc Software bvba, Ostend, Belgium).

\section{Results}

In total, 268 liver biopsies were performed during the study period. Among these patients, 234 (87.3\%) of them were $\mathrm{HBeAg}$ negative (140 males, 94 females). So, further evaluation was done with these patients according to our inclusion criteria. Mean age of $\mathrm{HBeAg}$ negative patients was $41.5 \pm 11.3$ years. Mean ALT value was $56.9 \mathrm{U} / \mathrm{L}$ and 116 (49.6\%) of them have ALT in the normal range. Of the patients, 142 (60.7\%) had HBV-DNA > 20.000IU/mL. Baseline demographic and other characteristics of patients are shown in Table 1. 
Table 1. Baseline characteristics of hepatitis B e antigen-negative patients

\begin{tabular}{|l|l|}
\hline $\mathbf{n}$ & $\mathbf{2 3 4}$ \\
\hline Age & $41.50 \pm 11.3$ \\
\hline HBV-DNA IU/mL & 33682 (7756.5-939050.5) \\
\hline Log (HBV-DNA) IU/mL & $4.53(3.89-5.97)$ \\
\hline Alanine aminotransferase U/L & $56.9 \pm 69$ \\
\hline Aspartate aminotransferase U/L & $39.8 \pm 34$ \\
\hline Gamma-glutamyltransferase U/L & $25.5 \pm 19.6$ \\
\hline Alpha-fetoprotein ng/mL & $4.5 \pm 7.5$ \\
\hline $\begin{array}{l}\text { Median of histology activity index } \\
\text { (range) }\end{array}$ & $5(1-16)$ \\
\hline Median of fibrosis (range) & $2(0-5)$ \\
\hline $\begin{array}{l}\text { Data were shown as mean } \pm \text { standard deviation and median (Interquartile range) } \\
\text { HBV: Hepatitis B virus }\end{array}$ \\
\hline
\end{tabular}

Patients' total necroinflammatory score median was 5 (range: 1-16) and the fibrosis component was 2 (range: 0-5). Of the total, $31(13.2 \%)$ patients had no fibrosis, 162 (69.2\%) had portal fibrotic expansion (stages 1 and 2), 38 (16.2\%) had bridging fibrosis (stages 3 and 4 ), and 3 (1.3\%) had cirrhosis (stage 5). Among 31 patients who had no fibrosis, 28 patients had also $\leq 4$ necroinflammatory scores, 12 patients had $<20.000 \mathrm{IU} / \mathrm{mL}$ HBV-DNA, and 20 patients had normal ALT levels.

A total of 74 (31.6 \%) patients' liver biopsy was evaluated as in normal or minimally affected liver. In univariate analysis, all baseline characteristics except mean HBV-DNA value were statistically different between NL and $\mathrm{CH}$ (Table 2). When patients analyzed by grouping with HBV-DNA level, meaningful statistical difference was observed between $\mathrm{NL}$ and $\mathrm{CH}$ if the cut off value was accepted as $100.000 \mathrm{IU} / \mathrm{mL}(p=0.04)$ or $1.000 .000 \mathrm{IU} / \mathrm{mL}(p=0.005)$. Statistical difference was not found when the cut off value of HBV-DNA was accepted as $<20.000 \mathrm{IU} / \mathrm{mL}$ ( $p=0.65$ ) (Table 2).

\begin{tabular}{|c|c|c|c|c|}
\hline \multicolumn{2}{|c|}{ Characteristics } & $\begin{array}{l}\text { Normal or minimally affected Liver group } \\
(\mathrm{n}=74)\end{array}$ & $\begin{array}{l}\text { Chronic hepatitis group } \\
(n=160)\end{array}$ & p \\
\hline \multicolumn{2}{|c|}{ Gender (male) } & $37(50.0)$ & $103(64.4)$ & 0.037 \\
\hline \multicolumn{2}{|c|}{ Age (years) } & $37 \pm 11.4$ & $43.5 \pm 10.8$ & $<0.001$ \\
\hline \multicolumn{2}{|c|}{ HBV-DNA IU/mL } & $25.9 \times 10^{3}\left(7.7 \times 10^{3}-134.6 \times 10^{3}\right)$ & $45.8 \times 10^{3}\left(7,7 \times 10^{3}-1696,2 \times 10^{3}\right)$ & 0.161 \\
\hline \multicolumn{2}{|l|}{ ALT U/L } & $27.5(20-39.5)$ & $45(23-83)$ & $<0.001$ \\
\hline \multicolumn{2}{|l|}{ AST U/L } & $24(22-33)$ & $34(24-49)$ & $<0.001$ \\
\hline \multicolumn{2}{|l|}{ GGT U/L } & $17(12-23)$ & $23(15-32)$ & $<0.001$ \\
\hline \multicolumn{2}{|c|}{ AFP ng/mL } & $2.5(1.7-3.4)$ & $3.2(2.35-4,8)$ & 0.002 \\
\hline \multicolumn{2}{|l|}{ HAI } & $3(2-4)$ & $6(5-8)$ & $<0.001$ \\
\hline \multicolumn{2}{|l|}{ HAI (>4) } & 0 & $122(76.3)$ & $<0.001$ \\
\hline \multicolumn{2}{|l|}{ Fibrozis } & $1(0-1)$ & $2(2-3)$ & $<0.001$ \\
\hline \multicolumn{2}{|c|}{ Fibrozis $(>1)$} & 0 & $123(76.9)$ & $<0.001$ \\
\hline \multirow{3}{*}{$\begin{array}{l}\text { HBV-DNA } \\
\text { Level }\end{array}$} & $>20.000$ & $44(59.4)$ & $100(42.7)$ & 0.65 \\
\hline & $>100.000 \mathrm{IU} / \mathrm{mL}$ & $20(27)$ & $65(40.6)$ & 0.04 \\
\hline & $>1.000 .000 \mathrm{IU} / \mathrm{mL}$ & $9(12.2)$ & $46(28.8)$ & 0.005 \\
\hline
\end{tabular}

Table 3. Results of receiver operating characteristic analysis for various biomarkers in predicting chronic hepatitis compared to normal or minimally affected liver

\begin{tabular}{|c|c|c|c|c|c|}
\hline & HBV-DNA & ALT & AST & GGT & AFP \\
\hline AUC & 0.557 & 0.658 & 0.694 & 0.649 & 0.646 \\
\hline Cl $95 \%$ of AUC & $0.491-0.622$ & 0.594-0.719 & $0.631-0.753$ & $0.582-0.712$ & $0.570-0.717$ \\
\hline Cut-off point & $>789.3 \times 10^{3}$ & $>45$ & $>29$ & $>25$ & $>2.5$ \\
\hline Sensitivity & 32.5 & 49.38 & 63.52 & 42.38 & 71.90 \\
\hline NPV & 37.6 & 43.4 & 46.3 & 40.0 & 43.3 \\
\hline
\end{tabular}

HBV: Hepatitis B virus, ALT: Alanine aminotransferase, AST: Aspartate aminotransferase, GGT: Gamma-glutamyl transpeptidase, AFP: Alpha-fetoprotein, AUC: Area Under the ROC Curve, Cl: Confidence interval, PPV: Positive predictive value, NPV: Negative predictive value 


\begin{tabular}{|l|l|l|l|l|l|}
\hline Table 4. A multivariate logistic regression model of biomarkers and other covariates associated with chronic hepatitis \\
\hline Independent variables & $\boldsymbol{\beta}$ & $\mathbf{S E}$ of $\boldsymbol{\beta}$ & $\mathbf{p}$ & $\mathbf{0 R}$ & $\mathbf{9 5 \%}$ CI for OR \\
\hline ALT U/L & 0.001 & 0.015 & 0.971 & 1.001 & $0.971-1.031$ \\
\hline AST U/L & 0.072 & 0.034 & $\mathbf{0 . 0 3 4}$ & 1.074 & $1.005-1.148$ \\
\hline GGT U/L & 0.004 & 0.016 & 0.785 & 1.004 & $0.974-1.036$ \\
\hline AFP ng/mL & 0.167 & 0.083 & $\mathbf{0 . 0 4 5}$ & 1.182 & $1.004-1.392$ \\
\hline Age (years) & 0.056 & 0.020 & $\mathbf{0 . 0 0 5}$ & 1.058 & $1.017-1.099$ \\
\hline Gender (male) & 0.453 & 0.434 & 0.296 & 1.574 & $0.673-3.681$ \\
\hline
\end{tabular}

$\beta$ : Regression coefficient, SE: Standard error, OR: Odds Ratio, Cl: Confidence interval, ALT: Alanine aminotransferase, AST: Aspartate aminotransferase, GGT: Gammaglutamyl transpeptidase, AFP: Alpha-fetoprotein

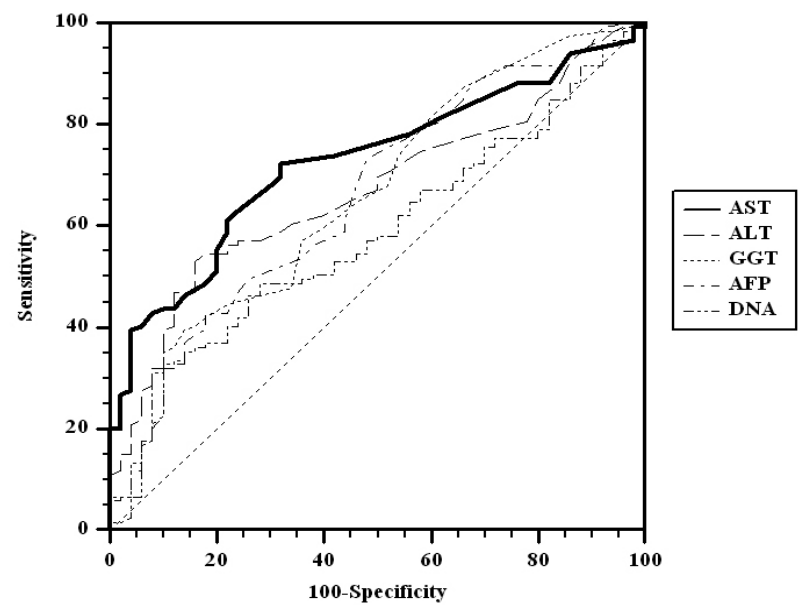

Figure 1. ROC analysis of laboratory results

ROC: Receiver operating characteristic, AST: Aspartate aminotransferase, ALT: Alanine aminotransferase, GGT: Gamma-glutamyl transpeptidase, AFP: Alphafetoprotein

ROC curve analysis was performed and the optimal cut-off ALT, AST, GGT, and AFP values were determined for identifying $\mathrm{CH}$. The AUC values were derived as 0.658 (95\% confidence interval $(C l)=0.594$ to 0.719 ) for $A L T, 0.694$ (95\% Cl=0.631 to 0.753 ) for AST, and $0.649(95 \% \mathrm{Cl}=0.582$ to 0.712$)$ for GGT. AST levels higher than $29 \mathrm{U} / \mathrm{L}$ have $63.52 \%$ sensitivity and $67.57 \%$ specifity for $\mathrm{CH}$. Similarly AFP levels higher than $2.5 \mathrm{U} / \mathrm{L}$ have $71.9 \%$ sensitivity and $50.98 \%$ specifity for $\mathrm{CH}$. The results of $\mathrm{ROC}$ curve analysis are shown in Table 3.

Multivariate logistic regression analysis was performed in order to identify factors associated with $\mathrm{CH}$. Age, AST, and AFP were the significant independent risk factors for $\mathrm{CH}$. The results of multivariate logistic regression analysis are shown in Table 4.

\section{Discussion}

In this study, we investigated associations between $\mathrm{CH}$ and some demographic and laboratory parameters such as age, gender, ALT, AST, GGT, AFP, and HBV-DNA in HBeAg-negative CHB patients. According to our results, age, gender, ALT, AST GGT, AFP, and HBV-DNA levels $>100.000 \mathrm{IU} / \mathrm{mL}$ were associated with $\mathrm{CH}$ in univariate analysis. However in multivariate analysis only age, AST and AFP levels were associated with $\mathrm{CH}$.

AST and ALT are normally contained in liver cells. In liver diseases such as in viral hepatitis, the liver cells spill the enzymes into the blood, raising the enzyme levels in the blood and signaling that the liver was damaged (8). In a study which was investigated relationship between histopathological features of liver and serum transaminase levels, AST was found a better laboratory screening test for finding the severity of liver injury than ALT in HBeAgnegative CHB patients (9). Similarly, our results showed that AST levels are more useful in showing liver damage than ALT. The normal limits of AST have been investigated in very few studies. It is recommended to adopt $40 \mathrm{U} / \mathrm{L}$ as the upper limit of AST (10). This value may be different in cases who have stage 3 or higher fibrosis, which was very low in our study. Inthis study the cut off level of AST was found to be $29 \mathrm{U} / \mathrm{L}$. This suggests that normal AST levels in our country should be determined by large epidemiological studies.

Our results indicate that high levels of AFP was the second independent laboratory parameter related with $\mathrm{CH}$. AFP is a glycoprotein that normally produced in early pregnancy by the fetal yolk sac, liver and gastrointestinal tract (11). In adults, AFP levels are elevated in acute or chronic viral hepatitis, chronic liver disease, non-alcoholic fatty liver disease, and especially in gonadal tumors and hepatocellular carcinoma (12). Also, it was shown that elevated serum AFP levels are associated with hepatic steatosis and $\geq$ stage 2 fibrosis (13). Elevated serum AFP levels in these hepatic diseases are depend on the ongoing inflammation, altered hepatocyte-hepatocyte interaction or the loss of normal achitectural arrangements (14). According to our results, the cut off point of AFP is $2.5 \mathrm{ng} / \mathrm{mL}$. However, this cut-off value is under the ULN value for AFP. This situtation might be related with observer difference in our pathologists.

Age was another parameter found as a prognostic factor for $\mathrm{CH}$. The relationship between age and fibrosis was found in multiple studies. the average age was found lower in patients with mild fibrosis than in those with severe fibrosis (15). In another study, positive correlation was found between age and fibrosis, too (16). It should be noted that the duration of the disease may also be related to the fibrosis score. Our results revealed that the average age was higher in $\mathrm{HBeAg}$-negative $\mathrm{CHB}$ patients with $\mathrm{CH}$ than in those with NL (43.5 years vs 37 years). Interestingly, according to our results, HBV-DNA level does not predict the necroinflammation and fibrosis. This finding has also been mentioned in other studies. Lu et al. (17) and Aktug Demir et al. (16) reported no correlation between the viral load, inflammatory activity, and the fibrosis score. As the risk of $\mathrm{CH}$ increases with age, patients should be followed up very closely after the age of 40 years and liver biopsy should be considered even if HBV-DNA levels and other liver tests such as 
ALT are not too high. This is also important in determining the age at which treatment begins. Patients more than 40 years old should be evaluate for treatment be carefully because this age is critical for fibrozis.

\section{Study Limitations}

Before any conclusion we should declare our limitations. One of our limitation is that, we could not evaluate the effect of platelet results for fibrosis. Our other limitation is that, we did not investigate the pathologist observation difference. If we did it, we could been say more accurate results.

\section{Conclusion}

As a result, age, high AST anf AFP levels are associated with hepatic necroinflammation in $\mathrm{HBeAg}$-negative $\mathrm{CHB}$. Specialist doctors who follow up these patients should evaluate these parameters more carefully.

\section{Ethics}

Ethics Committee Approval: The study protocol was approved by the Ethics Committee of Sakarya University Faculty of Medicine (approval number: 2013/71522473.050.01.04/37).

Informed consent: Retrospective study.

Peer-review: External and internal peer-reviewed.

\section{Author Contributions}

Concept: E.G., Design: E.G., A.Ö., O.K., Data Collection or Processing: E.G., A.Ö., M.K., O.K., Analysis or Interpretation: E.G., Ü.E., O.K., Literature Search: E.G., A.Ö., Writing: E.G., A.Ö., O.K.

Conflict of Interest: No conflict of interest was declared by the author.

Financial Disclosure: The authors declared that this study received no financial support.

\section{References}

1. Lampertico $P$, Agarwal $K$, Berg $T$, Buti $M$, Janssen HLA Papatheodoridis G, Zoulim F, Tacke F. EASL 2017 Clinical Practice Guidelines on the management of hepatitis B virus infection. J Hepatol. 2017;67:370-398.

2. Tozun N, Ozdogan $\mathrm{O}$, Cakaloglu $\mathrm{Y}$, Idilman R, Karasu Z, Akarca U, Kaymakoglu S, Ergonul O. Seroprevalence of hepatitis B and C virus infections and risk factors in Turkey: a fieldwork TURHEP study. Clin Microbiol Infect. 2015;21:1020-1026.

3. Özkan H. Epidemiology of Chronic Hepatitis B in Turkey. Euroasian J Hepatogastroenterol. 2018;8:73-74.

4. Wang H, Xue L, Yan R, Zhou Y, Wang MS, Cheng MJ, Hai-Jun Huang. Comparison of histologic characteristics of Chinese chronic hepatitis B Patients with persistently normal or mildly elevated ALT. PLoS One. 2013;8:e80585
5. Keeffe EB, Dieterich DT, Han SH, Jacobson IM, Martin P, Schiff $\mathrm{ER}$, Tobias H. A treatment algorithm for the management of chronic hepatitis B virus infection in the United States: 2008 update. Clin Gastroenterol Hepatol. 2008;6:1315-1341.

6. Papatheodoridis GV, Manolakopoulos S, Liaw YF, Lok A. Followup and indications for liver biopsy in $\mathrm{HBeAg}$-negative chronic hepatitis B virus infection with persistently normal ALT: a systematic review. J Hepatol. 2012;57:196-202.

7. Knodell RG, Ishak KG, Black WC, Chen TS, Craig R, Kaplowitz N, Kiernan TW, Wollman J. Formulation and application of a numerical scoring system for assessing histological activity in asymptomatic chronic active hepatitis. Hepatology. 1981;1:431-435.

8. Lala V, Minter DA. Liver Function Tests. 2018 Oct 27. StatPearls [Internet]. Treasure Island (FL): StatPearls Publishing. 2018. Available from http://www.ncbi.nlm.nih.gov/books/NBK482489/

9. Hasanjani Roushan MR, Hajiahmadi M, Shafaie S. Histopathological features of liver and its relation to serum transaminase levels in 91 cases of anti-HBe-positive chronic hepatitis B. Int J Clin Pract. 2005;59:791-794.

10. Office of regulatory affairs, Office of operations. Investigations operation manual 2018. Available from https://www.fda.gov/ downloads/ICECI/Inspections/IOM/UCM607759.pdf

11. Anfuso S, Soncini E, Bonelli P, Piantelli G, Gramellini D. Secondtrimester maternal serum alpha-fetoprotein elevation and its association with adverse maternal/fetal outcome: ten years experience. Acta Biomed. 2007;78:214-219.

12. Babalı A, Çakal E, Purnak T, Bıyıkoğlu I, Çakal B, Yüksel O, Köklü S. Serum $\alpha$-fetoprotein levels in liver steatosis. Hepatol Int. 2009;3:551-555

13. Chen $\mathrm{CH}$, Lin $\mathrm{ST}$, Kuo $\mathrm{CL}$, Nien $\mathrm{CK}$. Clinical significance of elevated alpha-fetoprotein (AFP) in chronic hepatitis $\mathrm{C}$ without the patocellular carcinoma. Hepatogastroenterology. 2008;55:14231427.

14. Goldstein NS, Blue DE, Hankin R, Hunter S, Bayati N, Silverman AL, Gordon SC. Serum alpha-fetoprotein levels in patients with chronic hepatitis C. Relationships with serum alanine aminotransferase values, histologic activity index, and hepatocyte MIB-1 scores. Am J Clin Pathol. 1999;111:811-816.

15. Mohamadnejad M, Montazeri G, Fazlollahi A, Zamani F, Nasiri J, Nobakht H, Forouzanfar MH, Abedian S, Tavangar SM, Mohamadkhani A, Ghoujeghi F, Estakhri A, Nouri N, Farzadi Z, Najjari A, Malekzadeh R. Noninvasive markers of liver fibrosis and inflammation in chronic hepatitis B-virus related liver disease. Am J Gastroenterol. 2006;101:2537-2545.

16. Aktug Demir N, Kolgelier S, Ozcimen S, Gungor G, Sumer S, Saltuk Demir L, Inkaya AC, Ural O. Evaluation of the relation between hepatic fibrosis and basic laboratory parameters in patients with chronic hepatitis B fibrosis and basic laboratory parameters. Hepat Mon. 2014;14:e16975.

17. Lu LG, Zeng MD, Mao YM, Li JQ, Qiu DK, Fang JY, Cao AP, Wan MB, Li CZ, Ye J, Cai X, Chen CW, Wang JY, Wu SM, Zhu JS, Zhou $X Q$. Relationship between clinical and pathologic findings in patients with chronic liver diseases. World J Gastroenterol. 2003;9:2796-2800. 